\title{
Learning Styles and Study Habits of New University Students at a Public University in Mexico
}

\author{
Shamaly Alhelí Niño Carrasco, Ph.D. \\ Autonomous University of Baja California, México \\ Esperanza Viloria Hernández, Ph.D. \\ Autonomous University of Baja California, México \\ Victoria Elena Santillán Briceño, Ph.D. \\ Autonomous University of Baja California, México \\ Juan Carlos Castellanos Ramírez, Ph.D. \\ Autonomous University of Baja California, México
}

\begin{abstract}
The objective of this research is to identify the learning styles and study habits of new students of the Education, Psychology, Communication, Sociology, and History undergraduate programs of the School of Humanities at the Mexicali Campus of Universidad Autónoma de Baja California (UABC), in Mexico. The method is quantitative, with a sample of 650 students. The inventories used are the survey applied upon admission to the School of Humanities, and adaptations of the Learning Styles and Study Habits Inventories. The questionnaires were answered online by students who were already enrolled in the 2016-2017 school year. A sociodemographic profile of the students was established based on the results: $73 \%$ of enrolled students are female, and only $27 \%$ are male. The majority (70 \%) live with their families (father, mother, siblings); $75 \%$ of students do not work; $90 \%$ said they were single and $10 \%$ were married. The predominant learning styles out of the 13 dimensions are the factors associated with effort and frustration tolerance (.99), followed by a single and structured focus of attention (.98) and intrinsic motivation (.94). The primary study habits in the aspect of optimization are reading $32.8 \%$ and motivation to study $28.7 \%$. Conclusion: Comprehensive profiles that consider the sociodemographic background, learning styles and study habits are essential when dealing with new students.
\end{abstract}

Keywords: Learning Styles, Study Habits, Higher Education, Students.

\section{INTRODUCTION}

Students are one of the core resources of Higher Education Institutions. For this reason, educational policies that assess indicators associated with educational quality for the students, such as the appropriateness of curriculums, tutoring, completion rates, and linkage with productive sectors, have been generated in Mexico since the year 2000 (ANUIES, 2000). Despite all efforts to improve educational quality, several aspects should be considered for the proper attention of students who are admitted to Mexican public universities, since there is little information about the characteristics, knowledge, and skills with which they graduate from upper secondary education institutions (Estrada, 2014; García, Sánchez, Jiménez, \& Gutiérrez, 2012).

Therefore, this study proposes to establish a comprehensive profile of the university student with three indicators: sociodemographic characteristics, learning styles and study habits with 
which students start their undergraduate programs, considering that collecting information can contribute to the academic planning of university education (Aguilar, 2006; Navarro, 2008; Rinaudo, Chiecher, \& Donolo, 2003).

The sociodemographic indicator refers to a statistical dimension that collects and describes the characteristics of students according to their age, sex, economic resources and educational institution of origin. It also allows determining the number of students who will apply to university, those who move from other states, or those who travel from nearby communities (Romero \& Lavigne, 2004; Shapiro, 2011). The information collected from new students allows us to detect those who are at risk of not completing their undergraduate programs due to lack of economic resources. It also helps in to establish the type of pre-university education they have, which is what allows them to develop the skills and knowledge required for professional education (Juárez, Rodríguez, \& Luna, 2012).

Research on university student learning has revealed that the assessment of learning styles and study habits contributes to the timely detection of at-risk students so that psychopedagogical counseling or tutoring areas can adequately address them (Bermudez, 1998; Camarero, Martin del Buey, \& Herrero, 2000; Domínguez, Gutiérrez, Llontop, Villalobos, \& Delva, 2015).

The term "Learning Style" has been described from the perspective of different fields of study, and they have agreed on the fact that it refers to the ways in which a student learns, highlighting the cognitive, affective and physiological processes as consistent factors in the way they perceive, relate, and respond to their learning environments (Ventura, 2011).

The empirical data reported at the university level on learning styles research agree that it constitutes a support tool for the psychopedagogical departments within universities. In particular, it contributes to the recognition of the diversity of teaching and learning processes, as well as the variety of resources and techniques used in the classroom and curricular activities (Ventura, 2011).

Study habits have been developed as a type of behavior acquired by repetition or learning, which is done automatically. Notably, study habits are the methods and strategies used by students to access the knowledge contained in the learning units. These habits require effort, dedication, and discipline (Hernández, Rodríguez, \& Vargas, 2012). Recent research indicates that study habits in university students are significant contributors to academic achievement. Among the habits that have a positive influence on learning are time management, reading comprehension, class notes, memory, attention, and comprehension, as well as motivation, interpersonal relationships, and teamwork (Mondragón, Cardoso, \& Bobadilla, 2016; Torrez, Tolosa, Urrea, \& Monsalve, 2009).

Without a doubt, the assessment of learning styles and study habits is an essential tool that can be used as a factor to improve the educational performance of university students, as well as to guide their academic trajectories and professional careers.

\section{DEVELOPMENT OF INDICATORS}

The research done on the characteristics of new students is a starting point for the development of empirical indicators of educational trajectories. It is a strategy to predict academic performance, retention and comprehensive profiles of university students. 
First, it is important to highlight the progress achieved in data processing through the development and application of three instruments a) the new student survey that was implemented in 2009 with the goal of gathering information from students in order to identify their origin, educational background, motivations for choosing the institution, and program selection expectations (Blanco, 2000; Esquivel \& Rojas, 2005; Steinmann, Bosch, \& Aiassa, 2013); b) learning style inventories and c) study habits of the new student population. The last two were adapted for the population of the School of Humanities of Universidad Autónoma de Baja California (FCH), Mexico (Diaz Vega, 1990).

With the cooperation of the Graduate Follow Up Program, which is in charge of the SH online survey portal, the three questionnaires used by the Counseling and Psychopedagogy department were applied online for the first time. This innovation allowed for fast, timely and reliable processing of the results presented in the following pages.

\section{METHODOLOGY}

The objective of this research is to identify the learning styles and study habits of new students of the Education, Psychology, Communication, Sociology, and History undergraduate programs of the School of Humanities at the Mexicali Campus of Universidad Autónoma de Baja California (UABC), in Mexico.

\section{Population}

Students who were selected via the admission test to the common core of the Education, Psychology, Communication, Sociology, and History undergraduate programs of the School of Humanities of the Mexicali Campus of Universidad Autónoma de Baja California (UABC), in Mexico, for the 2016 and 2017 school years.

\section{Sample}

The 660 students who enrolled according to the Department of Student Affairs of UABC were considered for this research.

\section{Instruments}

Three instruments were used: the Socio-demographic Survey of the School of Humanities (SSSH), the Learning Styles Scale, which is an adaptation of the Learning Styles Inventory (LSI), and the adaptation of the Study Habits Inventory (SHI). The instruments are a product of studies conducted by Honey and Mumford (1986) and Wrenn (2003). These instruments are applied during the introductory courses that take place at the beginning of each semester. The results of the 2016 and 2017 school years are reported in this document.

\section{RESULTS}

The data described is a result of the application of the new student questionnaire, the Learning Styles Inventory, and the Study Habits Inventory to 650 School of Humanities students in the 2016 and 2017 school years, from a population of 660 students. Beginning with gender characteristics, Table 1 shows a high degree of feminization (Sierra \& Rodriguez, 2005) of enrollment, given that $73 \%$ of enrolled students are female and only $27 \%$ are male. 
Table 1

Total Number and Percentage of Students Enrolled in 2016 and 2017 by Gender $(\mathrm{N}=650)$

\begin{tabular}{lcc}
\hline & N & $\%$ \\
Male & 176 & 27 \\
Female & 474 & 73 \\
Total & 650 & 100
\end{tabular}

Source: It is developed by the authors based on the results of the questionnaire applied by the Psychopedagogy Department.

Regarding the data on institutions of origin, it should be highlighted that it is public institutions that achieve the highest percentages of admission to the School of Humanities. Table 2 indicates that of the 55 upper secondary education institutions from which the majority of students graduated, $60 \%$ are public, and $40 \%$ are private. It was found that the majority (70 $\%$ ) live with their families (father, mother, siblings), followed by those who live with other people to whom they are not related (20\%) and those who live alone $(10 \%)$.

Also, $75 \%$ of the students do not work and are considered full-time students, and the remaining $25 \%$ have part-time jobs to support their studies. $90 \%$ said they were single, and $10 \%$ are married (see Table 2).

Table 2

Percentages of Sociodemographic Data of New Students $(\mathrm{N}=650)$

$\mathrm{N} \%$

$\begin{array}{lll}\text { Upper Secondary Education } & & \\ \text { Institutions } & & \\ \text { Private } & 22 & 40 \\ \text { Public } & 33 & 60\end{array}$

Currently living with

Alone $\quad 65 \quad 10$

Nuclear family $\quad 455 \quad 70$

People to whom they are not related $\quad 130 \quad 20$

Works

Yes $\quad 163 \quad 25$

No $\quad 487 \quad 75$

Marital Status

Married $\quad 65 \quad 10$

Single $\quad 585 \quad 90$

Source: It is developed by the authors based on the results of the new student questionnaire.

Below are the results of the application of the Learning Styles Scale -a term that refers to the psychological process that each person uses to learn- and the Study Habits Scale, which are the behaviors that students practice regularly in order to introduce new concepts in the teachinglearning process.

The results of the application of the Learning Styles Scale show that of the 13 dimensions that were measured, effort and frustration tolerance was the style that obtained the highest average (11) among the 650 enrolled students, followed by intrinsic motivation (9.3) (see 
Table 3). It can also be noted in Table 3 that at the moment of performing the reliability analysis of the 13 dimensions, high and moderate factor loadings greater than .60 were obtained. The most critical factors are observed in dimension 11, associated with effort and frustration tolerance (.99), followed by factor 8 , single and structured focus of attention (.98) and 12, intrinsic motivation (.94).

Table 3

Reliability and Average of Learning Styles ( $\mathrm{N}=650)$

\begin{tabular}{lcc}
\hline & Cronbach's Alpha & Average \\
1. External Visual & .80 & 7.6 \\
2. Internal Visual & .70 & 7.0 \\
3. External Auditory & .60 & 5.4 \\
4. Internal Auditory & .70 & 7.0 \\
5. External Kinesthetic & .65 & 5.6 \\
6. Internal Kinesthetic & .60 & 7.5 \\
7. Multiple and Flexible Focus of Attention & .70 & 7.1 \\
8. Single and Structured Focus of Attention & .98 & 8.3 \\
9. Abstract Trend & .78 & 7.9 \\
10. Concrete Trend & .80 & 7.9 \\
11. Effort and Frustration Tolerance & .99 & 11.0 \\
12. Intrinsic Motivation & .94 & 9.3 \\
13. Extrinsic Motivation & .80 & 7.8 \\
\hline
\end{tabular}

Source: It is developed by the authors based on the results of the adaptation of the Learning Styles Inventory.

Regarding the answers obtained with the Study Habits Scale, which measures five dimensions, it was found that $22 \%$ of the students who enrolled in the School of Humanities are used to taking notes in class, $21.9 \%$ feel motivated to study, and $20.2 \%$ consider that they have positive attitudes and behaviors toward the study. It is worth mentioning that there are no differences in these habits between male and female (see Table 4).

Table 4

Percentage of Study Habits Used by Students Considering Gender ( $\mathrm{N}=650)$

\begin{tabular}{|c|c|c|c|c|}
\hline & & Male & Female & $\%$ \\
\hline TD: (Time Distribution) & & 18.4 & 17.8 & 17.9 \\
\hline MS: (Motivation to Study) & & 21.4 & 22.4 & 21.9 \\
\hline NC: (How to Take Notes in Class) & & 21.1 & 22.3 & 22.2 \\
\hline RO: (Reading Optimization) & & 18.2 & 17.7 & 17.8 \\
\hline AB: (Productive Attitudes and Behaviors Toward Study) & & 20.9 & 19.8 & 20.2 \\
\hline & Total & 100 & 100 & 100 \\
\hline
\end{tabular}

Source: It is developed by the authors based on the results of the adaptation of the Study Habits Inventory.

It was considered relevant to analyze the students' responses depending on the undergraduate program chosen at the moment of taking the admission exam and subsequent admission to the common core stage. On average, the five undergraduate programs share a preference for the learning style associated with effort and frustration tolerance: the average in Education was 65.4; in Psychology, 65.8; Communication 73.6; Sociology; 58.3; and History 40. On the other hand, the least used learning styles are kinesthetic, where the average for Education was 31, and for Sociology 22.5, and external auditory, where the average for Psychology was 32.5, for Communication was 36.4 and for History 10 (see Table 5). 
Table 5

Averages for Learning Styles considering the program chosen upon admission to the School of Humanities $(\mathrm{N}=650)$

\begin{tabular}{lccccc}
\hline & Education & Psychology & Communication & Sociology & History \\
& $\mathrm{N}=128$ & $\mathrm{~N}=424$ & $\mathrm{~N}=82$ & $\mathrm{~N}=12$ & $\mathrm{~N}=4$ \\
1. External Visual & 43.5 & 45.7 & 51.7 & 38.3 & 35 \\
2. Internal Visual & 39.7 & 42.9 & 45.9 & 35.0 & 25 \\
3. External Auditory & 32.1 & 32.5 & 36.4 & 26.6 & 10 \\
4. Internal Auditory & 39.6 & 43.3 & 44.0 & 36.6 & 35 \\
5. External Kinesthetic & 31.0 & 34.0 & 39.8 & 22.5 & 20 \\
6. Internal Kinesthetic & 43.5 & 46.2 & 47.4 & 35.8 & 20 \\
7. Multiple and Flexible Focus & 39.0 & 44.0 & 48.5 & 32.5 & 30 \\
8. Single and Structured Focus & 47.6 & 50.0 & 56.2 & 47.5 & 30 \\
9. Abstract Trend & 43.7 & 49.0 & 51.0 & 54.1 & 25 \\
10. Concrete Trend & 47.8 & 47.1 & 51.0 & 45.0 & 40 \\
11. Effort and Frustration & 65.4 & 65.8 & 73.6 & 58.3 & 40 \\
$\quad$ Tolerance & & & & 61.6 & 30 \\
12. Intrinsic Motivation & 55.0 & 55.7 & 62.9 & 42.0 & 25 \\
13. Extrinsic Motivation & 43.0 & 47.0 & 51.4 & \\
\hline
\end{tabular}

Source: It is developed by the authors based on the results of the adaptation of the Learning Styles Inventory.

Table 6 shows the analysis of study habit preferences by program, showing that the dimensions of time distribution and how to take notes are predominant in Education $(23.1 \%$ and $27.1 \%$, respectively), and the motivation to study and productive attitudes and behaviors toward study (28.7 \% and $19.2 \%$, respectively) are predominant in Psychology.

Regarding the Communication program, students favor two study habits: reading optimization and motivation to study (20.0\% and $19.3 \%$, respectively), while Sociology students favor three: productive attitudes and behaviors toward study, motivation to study, and how to take notes in class $(22.0 \%, 21.4 \%$, and $21.0 \%$, respectively). Optimization of reading (32.8\%) stands out among History students (see Table 6).

Table 6

Percentage of Answers About Study Habits Depending on the Program Chosen Upon Admission to the School of Humanities $(\mathrm{N}=650)$

\begin{tabular}{lccccc}
\hline & Education & Psychology & Communication & Sociology & History \\
& $\mathrm{N}=128$ & $\mathrm{~N}=424$ & $\mathrm{~N}=82$ & $\mathrm{~N}=12$ & $\mathrm{~N}=4$ \\
TD: (Time Distribution) & 23.1 & 16.2 & 16.7 & 16.6 & 22.5 \\
MS: (Motivation to Study) & 19.1 & 28.7 & 19.3 & 21.4 & 12.0 \\
NC: (How to Take Notes in Class) & 27.1 & 18.7 & 16.2 & 21.0 & 16.0 \\
RO: (Reading Optimization) & 14.3 & 17.2 & 20.0 & 19.0 & 32.8 \\
AB: (Productive Attitudes and & 16.4 & 19.2 & 18.9 & 22.0 & 16.7 \\
Behaviors Toward Study) & & & & & \\
\hline
\end{tabular}

Source: It is developed by the authors based on the results of the adaptation of the Study Habits Inventory. 


\section{CONCLUSIONS}

In the short-term, continuing to process the general background, learning styles and study habits of newly admitted students will allow having profiles and dropout prediction systems, as well as dropout prevention programs with more efficient support interventions (Cano, 2008; León, 2005).

Comprehensive profiles that consider socio-demographic aspects, as well as learning styles and study habits, contribute to the creation of an assessment tool that helps identify the differences of new students since early detection of such deficiencies allows for the implementation of support mechanisms that facilitate learning and increase retention of university students.

Follow-up of the results of admission tests is proposed, since they can serve as predictors of academic achievement of new students, considering that positive correlations have been found between test scores and achievement. However, other factors should be considered for such predictions, such as educational background, study habits, attitudes or motivation (Tirado, Backhoff, Larrazolo, \& Rosas, 1997; Arias, Chávez, \& Muñoz, 2006, Viloria \& Santillán, 2018). Finally, the implementation of other studies focused on the educational trajectories of students at different moments of their undergraduate programs is suggested.

\section{References}

Aguilar, M. A. (2006). Problemas emocionales. Mexico: Instituto Michoacano de Ciencias de la Educación. Retrieved from: http://imced.edu.mx/tesis/problemasemocionales.pdf

Arias, F., Chávez, A., \& Muñoz, I. (2006). El aprovechamiento previo y la escuela de procedencia como predictores del aprovechamiento futuro: Un caso. Enseñanza e Investigación en Psicología, 11(1), 5-22. Retrieved from: https://www.redalyc.org/html/292/29211101/

Asociación Nacional de Universidades e Instituciones de Educación Superior (ANUIES). (2000). La educación superior en el Siglo XXI: líneas estratégicas de desarrollo, una propuesta de la ANUIES. Mexico: Asociación Nacional de Universidades e Instituciones de Educación Superior.

Bermúdez, M. T. (1998). La función psicopedagógica en el contexto universitario: el caso de la UABC. Mexico: Universidad Autónoma de Baja California.

Blanco, I. (2000). Fundamentos pedagógicos. Validaciones estadísticas. Mexico: Habilmind. Retrieved from: https://www.habilmind.com/images/fundamentos-validaciones-habilmind.pdf

Camarero, F., Martin del Buey, F., \& Herrero, J. (2000). Estilos y estrategias de aprendizaje en estudiantes universitarios. Psicothema Magazine, 12(4), 615-622. Retrieved from: http://www.psicothema.com/pdf/380.pdf

Cano, M. (2008). Motivación y elección de carrera. Revista Mexicana de Orientación Educativa, 5(13), 6-9.

Retrieved from: http://pepsic.bvsalud.org/pdf/remo/v5n13/v5n13a03.pdf

Díaz, V. J. L. (1990). Aprende a estudiar con éxito. México: Trillas.

Domínguez, H. J., Gutiérrez, J. A., Llontop, M., Villalobos, D., \& Delva, J.C. (2015). Estilos de aprendizaje: un estudio diagnóstico en el centro universitario de ciencias económico-administrativas de la U de G., Revista de la Educación Superior, 44(175), 121-140. https://doi.org/10.1016/j.resu.2015.09.005

Esquivel, L. A., \& Rojas, C. A. (2005). Motivos de estudiantes de nuevo ingreso para estudiar un posgrado en educación. Revista Iberoamericana de Educación, 36(5), 1-15. Retrieved from:

https://rieoei.org/RIE/article/view/2797

Estrada, M. J. (2014). Educación, política y proyecto de vida en los jóvenes. Mexico: El Colegio de Sonora.

García, J. L., Sánchez, C., Jiménez, M. A., \& Gutierrez, M. (2012). Estilos de aprendizaje y estrategias de aprendizaje: un estudio en discentes de postgrado. Journal of Learning Styles, 5(10), 65-78. Retrieved from:

http://learningstyles.uvu.edu/index.php/jls/article/view/109

Hernández, C. A., Rodríguez, N., \& Vargas, A. E. (2012). Los hábitos de estudio y motivación para el aprendizaje de los alumnos en tres carreras de ingeniería en un tecnológico federal de la ciudad de México. Revista de la Educación Superior, 41(163), 67-87. Retrieved from:

http://publicaciones.anuies.mx/pdfs/revista/Revista163_S1A3ES.pdf 
Honey, P., \& Mumford, A. (1986). The Manual of learning styles. Maidenhead: Peter Honey.

Juárez, C. S., Rodríguez, G., \& Luna, E. (2012). El cuestionario de estilos de aprendizaje CHAEA y la escala de estrategias de aprendizaje ACRA como herramienta potencial para la tutoría académica. Journal of Learning Styles, 5(10), 148-171. Retrieved from: http://learningstyles.uvu.edu/index.php/jls/article/view/113/76

León, O. (2005). La cultura científica y tecnológica en el tránsito a la sociedad del conocimiento. Revista de la Educación Superior, 34(136), 49-63. Retrieved from:

http://publicaciones.anuies.mx/pdfs/revista/Revista136_S2A2ES.pdf

Cardoso, D., \& Bobadilla, S. (2016). Study habits and academic performance: A research study of Business Administration undergraduate students at the Tejupilco Professional Academic Unit, 2016. RIDE Revista Iberoamericana para la Investigación y el Desarrollo Educativo, 8(15), 661-685. https://doi.org/10.23913/ride.v8i15.315

Navarro, M. J. (2008). Cómo diagnosticar y mejorar los estilos de aprendizaje. España: Procompal Publicaciones.

Rianudo, M. C., Chiecher, A., \& Donolo, D. Motivation and strategies use in university students. His evaluation from the Motivated Strategies Learning Questionnaire. Anales De Psicología/Annals of Psychology, 19(1), 107-119. Retrieved from https://revistas.um.es/analesps/article/view/27901

Romero, J. F., \& Lavigne, R. (2004). Dificultades en el Aprendizaje: Unificación de Criterios Diagnósticos. Andalucía: Tecnographic. S.L. Retrieved from: https://www.uma.es/media/files/LIBRO_I.pdf

Shapiro, B. K. (2011). Bajo rendimiento escolar: una perspectiva desde el desarrollo del sistema nervioso. Revista Médica Clínica Las Condes, 22(2), 218-225. https://doi.org/10.1016/S0716-8640(11)70416-3

Sierra, R., \& Rodríguez, G. (2005). Feminización de la matrícula de educación superior en América Latina y el Caribe. México: Unión de Universidades de América Latina. Retrieved from: http://132.247.171.154:8080/handle/Rep$\underline{\text { UDUAL/23 }}$

Steinmann, A., Bosch, B., \& Aiassa D. (2013). Motivación y expectativas de los estudiantes por aprender ciencias en la universidad: un estudio exploratorio. Revista mexicana de investigación educativa, 18(57), 585-598. Retrieved from: http://www.comie.org.mx/revista/v2018/rmie/index.php/nrmie/article/view/259/259

Tirado, F., Backhoff, E., Larrazolo, N., \& Rosas, M. (1997). Validez predictiva del Examen de Habilidades y Conocimientos Básicos (EXHCOBA). Revista Mexicana de Investigación Educativa, 2(3), 67-84. Retrieved from: http://www.comie.org.mx/revista/v2018/rmie/index.php/nrmie/article/view/1057/1057

Torres, M., Tolosa, I., Urrea, M., \& Monsalve, A. (2009). Hábitos de estudio vs fracaso académico. Revista Educación, 33(2), 15-24. https://doi.org/10.15517/REVEDU.V33I2.502

Ventura, A. C. (2011). Estilos de aprendizaje y prácticas de enseñanza en la universidad. Un binomio que sustenta la calidad educativa. Perfiles educativos, 33(SPE), 142-154. Retrieved from:

http://www.iisue.unam.mx/perfiles/articulo/2011-e-estilos-de-aprendizaje-y-practicas-de-ensenanza-en-launiversidad-un-binomio-que-sustenta-la-calidad-educativa.pdf

Viloria Hernández, E., \& Santillán Briceño, V. E. (2018). Trayectorias escolares de los estudiantes de la Facultad de Ciencias Humanas. In E. Viloria Hernández, V. E. Santillán, J. Soto, \& S. Cruz (comps.), Indicadores y trayectorias escolares de los estudiantes de la Facultad de Ciencias Humanas de la UABC (p.41-58). Mexico: Universidad Autónoma de Baja California.

Wrenn, H. (2003). Inventario de hábitos de estudio. Mexico: Editorial Prentice Hall 